\title{
Predicting Ailanthus altissima presence across a managed forest landscape in southeast Ohio
}

\author{
Louis R. Iverson * (D), Joanne Rebbeck, Matthew P. Peters, Todd Hutchinson and Timothy Fox
}

\begin{abstract}
Background: The negative impacts of the exotic tree, Ailanthus altissima (tree-of-heaven, stink tree), is spreading throughout much of the Eastern United States. When forests are disturbed, it can invade and expand quickly if seed sources are nearby.

Methods: We conducted studies at the highly dissected Tar Hollow State Forest (THSF) in southeastern Ohio USA, where Ailanthus is widely distributed within the forest, harvests have been ongoing for decades, and prescribed fire had been applied to about a quarter of the study area. Our intention was to develop models to evaluate the relationship of Ailanthus presence to prescribed fire, harvesting activity, and other landscape characteristics, using this Ohio location as a case study. Field assessments of the demography of Ailanthus and other stand attributes (e.g., fire, harvesting, stand structure) were conducted on 267 sample plots on a 400-m grid throughout THSF, supplemented by identification of Ailanthus seed-sources via digital aerial sketch mapping during the dormant season. Statistical modeling tools Random Forest (RF), Classification and Regression Trees (CART), and Maxent were used to assess relationships among attributes, then model habitats suitable for Ailanthus presence.
\end{abstract}

Results: In all, 41 variables were considered in the models, including variables related to management activities, soil characteristics, topography, and vegetation structure (derived from LiDAR). The most important predictor of Ailanthus presence was some measure of recent timber harvest, either mapped harvest history (CART) or LiDARderived canopy height (Maxent). Importantly, neither prescribed fire or soil variables appeared as important predictors of Ailanthus presence or absence in any of the models of the THSF.

Conclusions: These modeling techniques provide tools and methodologies for assessing landscapes for Ailanthus invasion, as well as those areas with higher potentials for invasion should seed sources become available. Though a case study on an Ohio forest, these tools can be modified for use anywhere Ailanthus is invading.

Keywords: Ohio, Random Forest, CART, Maxent, Landscape model, Non-native invasive species

\section{Background}

Throughout much of the Central Hardwoods region, the sustainability of oak forests is threatened by poor regeneration and ever-increasing abundances of shade-tolerant and/or fire-sensitive tree species (Johnson et al. 2009). In response, the use of partial harvest and/or prescribed fire on public lands has increased rapidly in the last decade (Iverson et al. 2017). While these management techniques can favor oak regeneration, their use may also increase the

\footnotetext{
* Correspondence: louis.iverson@usda.gov

Northern Research Station, USDA Forest Service, 359 Main Road, Delaware, $\mathrm{OH} 43015$, USA
}

risk of invasion and expansion of non-native plant species. Ailanthus altissima (tree-of-heaven, Chinese sumac, stink tree), native to northeastern China, was introduced into North America as an ornamental tree to Philadelphia in 1784, again in New York in 1820, and again in California during the Gold Rush of the mid-1880s, and its expansion quickly followed (Hu 1979; Kasson et al. 2013). It is classified as an 'aggressive invader' as it prefers disturbed, earlyseral habitats, can spread readily from root spouts, produces massive amounts of seed, and has rapid growth (Call and Nilsen 2005). It is widely distributed in the eastern U.S. and is highly invasive in disturbed habitats via 
establishment from prolific wind-dispersed seed (Bory and Clair-Maczulajtys 1980), and it can persist and expand via clonal growth (Kowarik 1995). It also has been shown to produce allelopathic compounds, furthering its invasive impact (Heisey 1996). Ailanthus is most often abundant in open sites such as roadsides but can invade disturbed forests, e.g., after windthrow, harvesting, or fire (Knapp and Canham 2000; Rebbeck et al. 2017). Though classified as shade-intolerant, it has been known to persist for extensive periods under shade (up to 20 years) and rapidly fill light niches following a disturbance event (Kowarik 1995; Knapp and Canham 2000). Further, it is drought tolerant and able to thrive in a host of poor soil conditions (Evans et al. 2006). It has been present in southern Ohio for at least 80 years and continues to spread (Drury and Runkle 2006).

Fire has often been shown to favor the expansion of non-native invasive species (NNIS) in the western U.S. (Zouhar et al. 2008). In the eastern U.S., NNIS are abundant and a major management concern; however, because large and high severity wildfires are infrequent and the widespread use of prescribed burning has begun only recently, much less in known about the effects of fire on invasives in this region (Dibble et al. 2008). Given that fire was an important process historically, the use of prescribed fire to sustain oak ecosystems has been widely promoted and is now being used more frequently as a management tool (Brose et al. 2014). Many National Forests in the eastern U.S. have adopted sustaining oak forests as an important objective in their Forest Management Plans (Yaussy et al. 2008), and state agencies are also embracing the use of prescribed fire to sustain mixed oak forests, enhance wildlife habitat, and reduce fuel loads (e.g., Ohio Division of Forestry 2010; Ohio Division of Wildlife 2015). A better understanding of how Ailanthus and other NNIS respond to prescribed fire in the eastern U.S. is important, so that proactive control strategies can be developed and integrated into prescribed fire and timber management programs at a landscape level.

Limited information is available on the direct and immediate effects of fire on Ailanthus. Though saplings are easily top-killed by fire, resprouting is prolific (Lewis 2007). Managers have observed increases in Ailanthus via sprouting and seed germination immediately following fires, presumably aided by top-kill, the reduced litter and increased light. However, in landscapes with very small populations of Ailanthus, it may not invade burned sites (e.g., Hutchinson et al. 2005). It remains unknown whether an extensive, post-burn Ailanthus establishment will inevitably occur when the Ailanthus propagule pressure is high.

Disturbance by timber harvesting has often facilitated the expansion of Ailanthus. The rapid establishment and growth, along with ample vegetative reproduction under relatively high light environments, make it particularly effective at invading sites after harvest (Call and Nilsen 2003). However, Kota et al. (2007) reported that the primary window for invasion occurs in the first year after disturbance, as suitable microsites rapidly decline as the native vegetation regrows.

This project was initiated to help gain a better understanding of how the distribution of Ailanthus is related to recent prescribed fires, harvesting activity, seed sources, and other landscape and stand characteristics, and with the intent to help develop prescriptions for managers to reduce the threat of post-fire or post-harvest invasion. It is a follow-on project of Rebbeck et al. (2017), which used the same study area to investigate plot-level trends and relationships to prescribed fire and harvest. This study focused on a landscape modeling approach through a series of different tools for analysis. Multiple tools were used, including digital aerial sketch mapping, field sampling, GIS analysis, and statistical modeling to quantify the distribution of Ailanthus and its most suitable (or unsuitable) habitat. The selected modeling tools included classification and regression trees (CART), Random Forests (RF) (Breiman 2001; Prasad et al. 2006), and maximum entropy (Maxent, Phillips and Dudík 2008; Elith et al. 2011). From these data and tools, we produce models and analyses of potential and likely factors related to the presence and abundance of Ailanthus across a forested landscape in Ohio, near the center of the Central Hardwoods region.

\section{Methods \\ Study site}

The Tar Hollow State Forest (THSF; 39 $21^{\prime} \mathrm{N} ; 82^{\circ} 46^{\prime} \mathrm{W}$ ) is located within Hocking, Vinton, and Ross counties of southern Ohio, and within the Southern Unglaciated Allegheny Plateau. Occupying 6618 ha (16,354 acres), its topography is highly dissected with three distinct landtypes: dry oak (on ridges and south facing slopes); dry-mesic mixed oak hardwood (on north-facing slopes); and rolling bottomland mixed hardwoods (on and near valley bottoms) (Iverson et al. 2018). The forest had a history of timber harvesting and farming from the time of European settlement in the late 1700 s to the 1930 s when a land utilization project funded the relocation of subsistence farming families to more productive land, leaving management to the state of Ohio. Reforestation of THSF was mostly from natural regeneration. Timber management has occurred since the 1940s and prescribed burning has been conducted since 2001. We focused sampling and modeling for the southern half of THSF ( $3884 \mathrm{ha}, 9600 \mathrm{ac}$ ), which included a known spatial history of prescribed fires and harvests. Tree cores from several large Ailanthus trees revealed that it has been present at THSF since at least the 1920s (J. Rebbeck unpublished). It is also present throughout southeastern Ohio, though its abundance is variable. In a 5- 
county area that includes THSH, Ailanthus was shown to be present in $5 \%$ of Forest Inventory and Analysis plots from the period 2006 to 2011 (Dyer and Hutchinson 2019).

An abundant establishment of Ailanthus from seed occurred following a thinning and prescribed fire treatment installed at THSF (Hutchinson et al. 2004). The combination of a seed source from a relatively small population of adult female trees in the stand along with forest floor and canopy disturbance during treatment appeared to be responsible for precipitating the increase in Ailanthus seedlings. An inventory on two adjacent treatment units (thin only or burn only) also revealed that on sites with only a few adult trees, the post-treatment increases in Ailanthus were much reduced (Hutchinson et al. 2004). The rapid expansion of Ailanthus after thinning and burning treatments prompted the Ohio Department of Natural Resources (ODNR) Division of Forestry and the Wayne National Forest to place more emphasis on NNIS management. Though an aggressive prescribed fire program, including multiple fire years can promote oak regeneration (Hutchinson et al. 2012), efforts must be made to minimize the expansion of NNIS such as Ailanthus. The THSF thus provides an ideal location to study the interactions of Ailanthus, harvesting, and fire.

\section{Ailanthus mapping and field sampling}

To provide a spatial representation of the presence of Ailanthus, seed-producing female Ailanthus trees were aerially mapped within the study area; male trees are not possible to map in this way (Rebbeck et al. 2015). Prominent seed clusters, often $>800$ per tree (Illick and Brouse 1926) persist through the winter and were easily identifiable in aerial surveys conducted in December 2008. Ground checks of 66 of the 96 aerially-identified female $A i$ lanthus (seed-bearing) trees occurred in January-February 2009. These mapped trees (Fig. 1) were used to help train and assess the Maxent model and assess the CART model (see below). Although annual seed production of individual

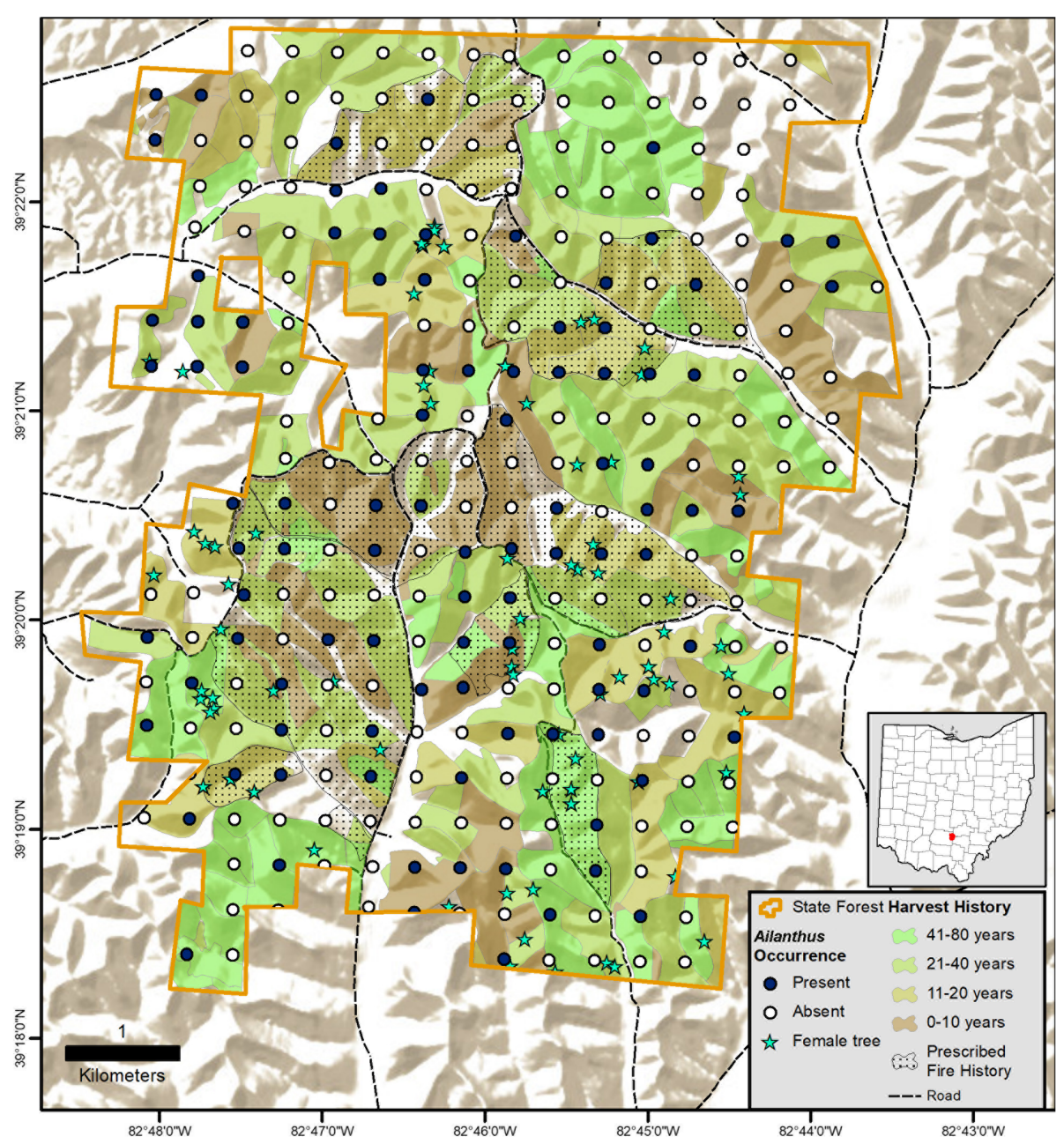

Fig. 1 Study area at Tar Hollow State Forest. Shown are female Ailanthus trees identified during helicopter surveys and $400 \mathrm{~m} \times 400 \mathrm{~m}$ grid of presence/ absence of Ailanthus on sample plots. Polygons represent areas harvested over 80 years along with prescribed fire history from $2001-2008$ 
Ailanthus trees can vary substantially, seed production has been shown to generally increase with tree diameter (Wickert et al. 2017).

A systematic grid of geo-referenced sample points ( $n=267,400 \mathrm{~m}$ spacing between plots) was established in late winter 2009 throughout the study area (Fig. 1), from which a series of data were collected on $40 \mathrm{~m}$ radius plots (Additional File 1). In summer 2009, we sampled woody vegetation on all plots using nested plots to estimate several size classes of Ailanthus (e.g., trees $\geq 10$ $\mathrm{cm}$ dbh, large saplings $\geq 3-9.9 \mathrm{~cm} \mathrm{dbh}$, small saplings $1.4 \mathrm{~m}$ height to $<3 \mathrm{~cm} \mathrm{dbh}$, seedlings $<1.4 \mathrm{~m}$ height), which included individual stems as well as root suckers and basal sprouts (see detailed sampling protocols in Rebbeck et al. 2017). In addition, if Ailanthus was not recorded in the nested plots, then we searched the entire $40 \mathrm{~m}$ radius plot to determine whether it was present in any size class. Notably, for this study, all Ailanthus plants, regardless of size, were collapsed to presence/absence on the plot to be the target variable and to increase sample size for modeling of the landscape-related variables in their relation (or not) to Ailanthus presence (or absence). A host of other vegetation variables were obtained from within $20 \mathrm{~m}$ radius plots at each grid point, including tree form, distance to skid road, distance to ridge top, percent sun via ceptometer, presence of canopy gaps, and evidence of past prescribed burn (see also Rebbeck et al. 2017, Additional File 1).

\section{GIS variables}

Because this was an exploratory effort to assess potential landscape-level influences on Ailanthus, a large number of GIS variables were collected and analyzed to search for relationships. As such, we present only those variables finally selected for models in the text, with descriptions of each in Additional File 1.

\section{Silvicultural history}

The Ohio Department of Natural Resources (ODNR, Forestry) provided digital GIS records of management history from 2005 through 2009, and access to earlier paper records of timber management history going back to the 1940s. Paper maps were digitally scanned and polygons of harvested areas were manually created within GIS software. A polygon database of harvest history was created which included the following attributes: harvest year, management unit, area harvested, volume removed, and silvicultural code related to harvest intensity (uncut, select, thin, multiple select cuts, or clearcut). For 30 unresolved gridpoints and their surrounding areas, ground surveys were conducted to estimate harvest history. Similarly, ODNR provided spatial data on the prescribed fire history and intensity (estimated as none, very low, low, medium, and high intensity) for the THSF. Prescribed fires between
2001 and 2008 covered approximately 25\% of the area within 10 units, and ranging in size from $8-323$ ha (20 to 800 acres).

\section{Terrain-derived variables}

A 10-m Digital Elevation Model (DEM) obtained from the Ohio Environmental Protection Agency, Division of Emergency and Remedial Response, was used to generate a series of variables, potentially useful in modeling Ailanthus habitat (Table 1, Additional File 1). These include the Integrated Moisture Index (IMI), a moisture regime index derived from curvature, flow accumulation, hillshade, and soil water holding capacity (Iverson et al. 1997; Peters et al. 2010). Flow direction and accumulation were created using an infinite directional algorithm (TauDEM v4.0, Tarboton 1997) which more accurately depicts the influence of terrain on soil moisture and overland flow. TauDEM was also used to generate the downslope influence and upslope dependence grids for each grid point and female trees individually.

Also created from the DEM were multiple terrainrelated features using Land Facet Corridor Designer tools from Jenness et al. (2011) that provides information related to position of a cell relative to the surrounding cells of $50,150,300$ and $600 \mathrm{~m}$. This topographic position index thus gives an indication of whether a cell is situated above or below the general landscape. Similarly, the slope position determined at radii of 50 and $300 \mathrm{~m}$ indicates, at two scales, topographic position at six positions ranging from valley bottom to ridgetop. These variables provide information relative to moisture retention.

Another series of variables provide information on solar radiation based on landscape position. These include hillshade (mentioned above), a Beer's transformation of aspect (Beers et al. 1966), an estimate of total solar radiation and an index of solar illumination (cumulative and relative proportion for each $2 \mathrm{~h}$ block of the day), and the relative solar radiation at $4 \mathrm{pm}$.

\section{Canopy height}

Light detection and ranging (LiDAR) data was used as a surrogate for harvest in the Maxent model. It can reflect canopy heights so that it will detect those locations with low tree height initially following harvest, followed by regrowth in the years following harvest. LiDAR was obtained from the State of Ohio (OSIP_I 2017) which had been collected between March-May (leaf-off) in 2008 with a mean point distance of $1.7 \mathrm{~m}(5.6 \mathrm{ft})$. The data contained first and last return heights and was classified into four categories (Default - cars, buildings, parts of vegetation, possible ground; Ground - bare earth points; Non-ground - vegetation returns or points identified to not be on the ground surface; and Low points - below ground surface). The ground points were used to create 
Table 1 Variables used in RF, CART, and Maxent models. NI-Not included. NC-Not Contributing to model. Description and statistics of variables are presented in Additional file 1

\begin{tabular}{|c|c|c|c|c|}
\hline Variable & RF rank & CART rank & Maxent Rank & Description \\
\hline Yrs_since_last_harvest & 1 & 1 & $\mathrm{Nl}$ & years since last harvest \\
\hline Near_Roads & 2 & $\mathrm{NI}$ & NC & distance from roads \\
\hline TPI600 & 3 & 3 & NC & TPI with $600 \mathrm{~m}$ buffer \\
\hline RelSun4pm & 4 & 2 & 6 & $\begin{array}{l}\text { relative solar radiation } \\
\text { at } 4 \mathrm{pm}\end{array}$ \\
\hline Near_Hike_Bridle & 5 & $\mathrm{Nl}$ & NC & distance from trails \\
\hline UpCanHt & 6 & $\mathrm{NI}$ & 4 & height of upper canopy \\
\hline Harvest_Yrs_cl & 7 & $\mathrm{NI}$ & $\mathrm{Nl}$ & years since harvest, class \\
\hline Fire_Int_cl & 8 & NC & NC & Intensity of fire \\
\hline TPI300 & 9 & 6 & 2 & TPI with $300 \mathrm{~m}$ buffer \\
\hline Elevation & 10 & $\mathrm{Nl}$ & 1 & Elevation (m) \\
\hline MidCanHt & 11 & $\mathrm{Nl}$ & NC & height of mid-canopy \\
\hline Asp_beer & 12 & NC & 3 & Beers aspect \\
\hline Near_Ridges_vec & 13 & $\mathrm{NI}$ & NC & distance from ridges \\
\hline Slope_deg & 14 & 4 & 9 & degree slope \\
\hline TAU_SCA & 15 & 7 & 7 & $\begin{array}{l}\text { specific catchment } \\
\text { area }\end{array}$ \\
\hline TPI50 & 16 & 5 & $\mathrm{NC}$ & TPI with $50 \mathrm{~m}$ buffer \\
\hline IMI & 17 & NC & 10 & $\begin{array}{l}\text { integrated moisture } \\
\text { index }\end{array}$ \\
\hline Percent_sun & 18 & $\mathrm{NI}$ & NC & percent sun at plot \\
\hline TotalSolar & 19 & $\mathrm{NI}$ & NC & total solar radiation \\
\hline Harvest_Int_cl & 20 & $\mathrm{Nl}$ & $\mathrm{NI}$ & harvest intensity, class \\
\hline Hillshade & 21 & NC & 12 & hillshade \\
\hline TPI150 & 22 & NC & NC & TPI with150 m buffer \\
\hline Curvature & 23 & $\mathrm{NC}$ & 13 & curvature \\
\hline LandFm50.300 m & 24 & NC & 14 & $\begin{array}{l}\text { landforms derived from } \\
\text { TPI }\end{array}$ \\
\hline Area_Sol_Rad & 25 & $\mathrm{NI}$ & 5 & annual solar radiation \\
\hline
\end{tabular}

a DEM from the minimum height of first and last returns within a 10-m grid, and where grids did not contain data, a $3 \times 3$ focal mean was used to fill gaps. Surface points (default and vegetation) were used to create a Digital Surface Model (DSM) from the maximum height of first and last returns. Canopy height was estimated by subtracting an adjusted DSM, where grids with null values were replaced with DEM values. Midstory is the minimum returns of vegetation that were then estimated by subtracting the DEM.

\section{Distance variables}

Distance from each grid point to several features on the landscape were calculated and included in the models. These included the distance to nearest bridle and hiking trail, road, and ridge line. The ArcHydro module (ESRI 2009) was used to develop drainage and ridge lines, from which each grid point was assayed for distance to nearest stream and ridge. Digital Line Graphs of road networks were obtained from the State (OGRIP) with a spatial resolution of 1:24,000 for the four $7.5 \mathrm{~min}$ quadrangles that encompass the study area (Hallsville, Laurelville, Londonderry, and Ratcliffburg).

\section{Data analysis and model development}

To determine the relationships of Ailanthus presence and abundance to distance from seed-producing trees, fire, timber harvest, and other landscape attributes, data analysis and modeling included several GIS and statistical techniques. Statistical relationships among variables were used to determine the possible drivers of Ailanthus presence and potential expansion within this landscape. The response variable related to Ailanthus used in the landscape models was the presence or absence of Ailanthus, of 
any size, on the plots. These were used in conjunction with attributes listed in Table 1 and Additional files 1 and 2 for mapping habitat affinities. In all, 41 variables were considered in the models, including variables related to management activities, soil characteristics, derived topographic measures, and vegetation structure characters (derived from LiDAR). Statistical tools included classical statistics, classification and regression trees (CART), Random Forests (RF) (Breiman 2001; Prasad et al. 2006), and maximum entropy (Maxent, Elith et al. 2011; Phillips and Dudík 2008), the latter three for modeling of suitable habitat affinity for Ailanthus. RF and CART use a similar statistical approach and have been used extensively to nonparametrically discern relationships in ecology, and to apply those relationships to predict for every cell across a raster map. These tools have the capacity to derive relationships among multiple variables, using out-of-bag randomization of subsets of data to limit concern for multicollinearity (Prasad et al. 2006). Similarly, Maxent has also been widely used, especially in prediction based on presence-only data. Though 41 variables were considered, the analyses quickly constrained variables to only a few non-correlated variables for model outputs. Because, from Rebbeck et al. (2017), we already knew that years since harvest was a primary predictor variable, we wished to pursue models with (CART and RF) and without (Maxent) this variable, as it is extremely difficult if not impossible to attain these spatial data across large public/private landscapes. We therefore used the CART model with the digitized polygons for THSF harvest history, and the Maxent model with the surrogate for harvest history, the LiDAR data. We chose to use both methods to investigate similarities, differences, and accuracy in the spatial predictions, including the value of the surrogate for harvest.

Model development was conducted in $\mathrm{R}$ ( $\mathrm{R}$ Core Team 2012) for Random Forest (RF), linear logistic regression, and CART and in Maxent software for Maxent. To select predictor variables most parsimonious for modeling, RF was run to assess variable importance and deviance explained. Linear logistic regression was used to evaluate individual variable relationships to presence/absence of Ailanthus across the plots. CART and Maxent outputs were used to generate maps of predicted presence/absence (CART) and probability of occurrence (Maxent). Model evaluation consisted of the pseudo $R^{2}$ for linear logistic regression, pseudo $R^{2}$ and Gini importance for RF, confusion matrix (Fielding and Bell 1997; Fawcett 2006) for CART and Maxent, and area under the receiver operating characteristic (AUC, Fielding and Bell 1997) for Maxent. The Gini importance ranks variable importance within RF and can be used as a general indicator of feature relevance; it measure how well a potential split is separating the samples of two classes within a particular node (Menze et al. 2009). Confusion matrices assess type I (false positives) and type II (false negatives) model errors. Values of AUC provide information about a model's sensitivity and specificity to classify data compared to random $(\mathrm{AUC} \leq 0.5)$.

\section{Results}

\section{Aerial survey and field sampling}

The helicopter survey allowed the mapping of 96 seedbearing Ailanthus females and 42 patches (up to 13.4 ha in size) containing Ailanthus within a 3884 ha THSF area (Rebbeck et al. 2015). Of the aerially mapped trees, 75 were ground-truthed, with only two trees incorrectly identified from the air. Further, $93 \%$ of the female Ailanthus trees identified were located within harvested areas within the THSF. When plotted, these Ailanthus trees were distributed across the study area, with the exception of the northeast portion (Fig. 1).

Among the 267 systematic plots ( $400 \mathrm{~m}$ grid) assessed across the landscape, Ailanthus seedlings were present on $22.5 \%$ of the plots and Ailanthus trees on $17 \%$ of plots. Ailanthus tree densities were either zero or less than 10 stems $\cdot \mathrm{ha}^{-1}$ in $86 \%$ of the plots; maximum tree density was 2193 trees.ha ${ }^{-1}$ on one plot. Seedlings density across all plots averaged 282 stems $\cdot \mathrm{ha}^{-1}$, but skewed by one plot which had 21,285 stems.ha ${ }^{-1}$. In areas with a harvest history within the past 40 years, $30 \%$ of the plots had Ailanthus seedlings and 21\% of the plots had Ailanthus trees; overall, $39 \%$ of these plots had some $A i$ lanthus. Medium to high densities ( $>100 \mathrm{ha}^{-1}$ ) of Ailanthus seedlings were found on $42 \%$ of plots within more recent $(<20 \mathrm{yr})$ harvests, 3.7 times as frequently as on plots harvested 21-80 years prior (Rebbeck et al. 2017).

Of the 267 plots, 55 (20.6\%) showed no evidence of harvest in the past 80 years, $23(8.6 \%)$ had been clearcut, mostly $>20$ years prior to this study, and 189 (70.1\%) had some form of selection harvest. Additionally, roughly $25 \%$ of the study area had dormant season prescribed fires between 2001 and 2008, four in the fall and 8 in the early spring (Fig. 1). Sampling of plots indicated that Ailanthus was present in 38 of the 80 plots (48\%) within the 890 ha $(2200 \mathrm{ac})$ that were burned. However, all but 9 of these burned plots (79\%) were also harvested within the last 40 years.

\section{Landscape modeling \\ Linear logistic regression/Random forest/CART modeling}

Linear logistic regression yielded a model with years since last harvest as the key influence on the presence of Ailanthus. It alone created a model reaching a pseudo $R^{2}$ of 0.30 . The more recent the harvest, the greater chance of finding Ailanthus. Of the 97 plot locations with Ailanthus present, 84 (87\%) had been harvested within the past 40 years. Variables also significant in model iterations using subsets of the data included, in decreasing order, relative sunlight intensity at $4 \mathrm{pm}$, topographic position index at 
$600 \mathrm{~m}$, and integrated moisture index. These last three variables reveal the following tendencies for Ailanthus presence: 1 ) it tends to occur where the relative sun intensity in late afternoon is not intense $(<0.26)$ especially on sites with recent harvests; 2) it tends to occur higher than most of the surrounding landscape within a radius of 600 $\mathrm{m}$; and 3) it tends to occur where soil moisture is moderate according to IMI: > 35 but mostly less than 48 (Iverson et al. 1997). A visual inspection of a map with IMI and locations of Ailanthus presence reveals a tendency for presence on relatively moist slopes but not the valley bottoms (Fig. 2).

Of the 41 variables assessed with Random Forest, 25 achieved a mean decrease in Gini importance $>1.5$. These are presented in decreasing rank order in Table 1, with the full list in Additional File 2. By far, the most important predictor of Ailanthus presence/absence was the years since last harvest. After that, distance to roads or trails, terrain-related variables (relative sunlight intensity at $4 \mathrm{pm}$, topographic position index at 600 and $300 \mathrm{~m}$, integrated moisture index), and LiDAR-derived variables (heights of mid- and upper canopy) appeared as important. The only fire-related variable that made this list of 25 was fire intensity class. The variables used in the CART and Maxent models used variables from this reduced set of 25 variables. The process of iterative modeling within CART or Maxent allowed us to parsimoniously further reduce the variable set, which also resulted in differing final data sets for CART vs. Maxent. A large exception to this approach was the elimination of 'years since harvest' from the Maxent data set (the most important variable in CART), with replacement with LIDAR-derived heights of upper and middle canopy; as discussed below, this was to test the potential for the LIDAR surrogates for years since harvest within Maxent.

Following RF, the CART model considered a reduced set of variables, in that we intended for the model to be more parsimonious and largely dependent on GIS-derived terrain-dependent variables along with years since harvest. As such, the final CART model presented here uses only

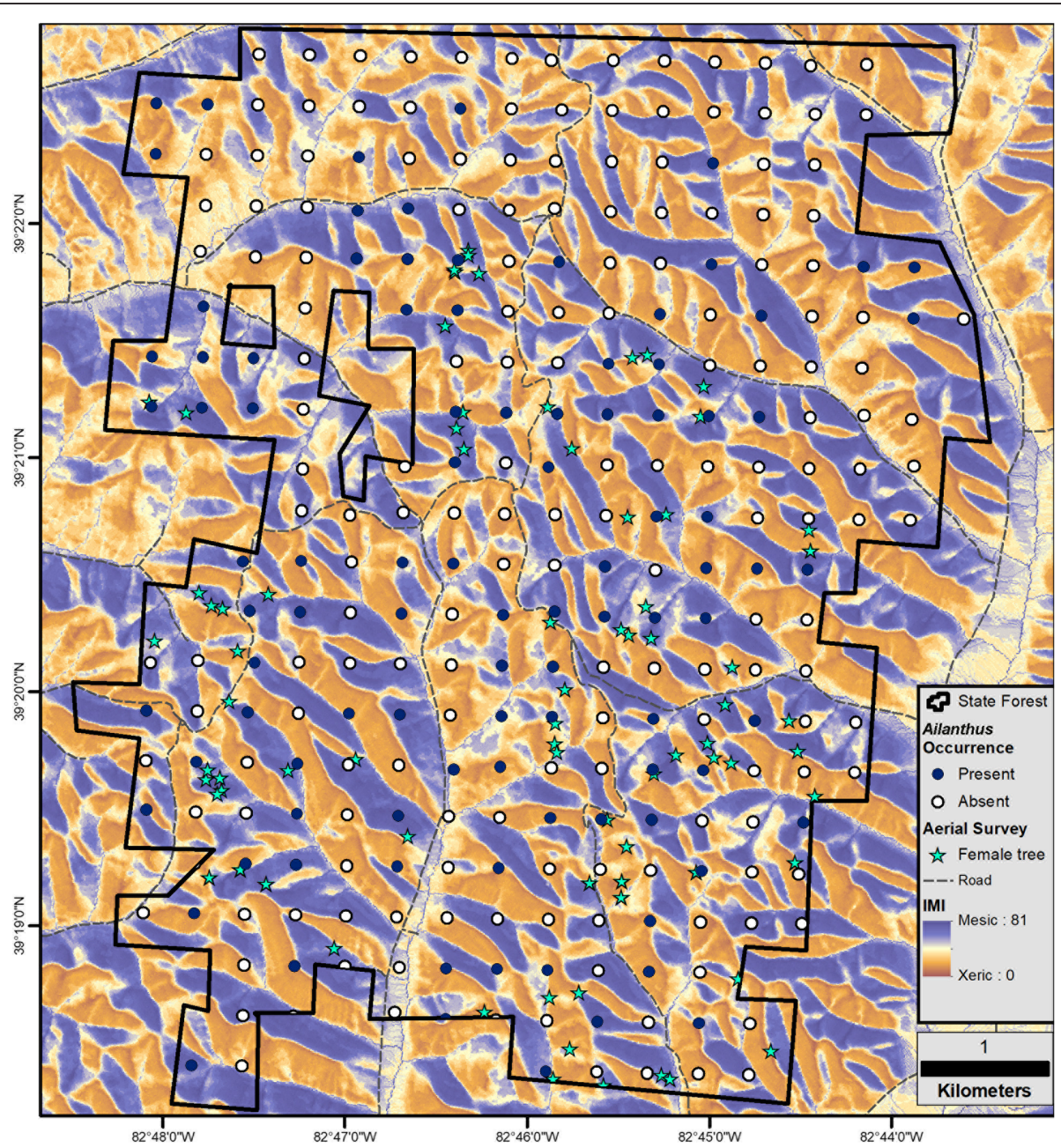

Fig. 2 Distribution of Ailanthus across Tar Hollow State Forest and integrated soil moisture index (IMI). Dark areas represent moist conditions 
the years since harvest and six terrain-related variables (Table 1, Additional File 3). The primary root split is years since harvest; the output shows Ailanthus was absent from $87 \%$ of the plots with no harvest in the past 65 years (Table 1, Additional File 3). Within the harvested areas, the model suggests that Ailanthus prefers aspects where the sun is less intense in the afternoon (RelSun4pm< 0.28). On harvested sites with less intense afternoon sun, Ailanthus is more common on the upper, steeper slopes, i.e., when the overall, broad terrain (topographic position index, or TPI, with a $600 \mathrm{~m}$ radius) is higher in elevation than the mean $600 \mathrm{~m}$ plane and if the slope angle is relatively steep ( $>42$ degrees). But other paths in the tree diagram show Ailanthus not specific to those upper, steeper slopes, as TPI at $150 \mathrm{~m}$ and TAU_SCA (flow accumulation of water downslope) indicate that Ailanthus presence can occur in much lower slope positions as well (Additional File 3).

The models also suggest conditions where Ailanthus presence would not be likely (Table 1, Additional File 3). Primarily, if the area was not recently harvested, Ailanthus is likely to be absent. But also locations with high intensity of afternoon sun are less likely for presence, whether the area was harvested or not.

It is also informative to mention the variables that did not factor in the models for presence or absence. Importantly, recent prescribed fire was not a significant predictor of Ailanthus presence or absence in any of the models. In addition, soil chemistry or texture variables were not significant in any of the models, nor were the variables associated with the downslope or downwind analyses.

When the CART model was applied via the significant predictors to the THSF landscape, a map of potential presence vs. absence was generated (Fig. 3). The map shows approximately $20.9 \%$ of the area as 'present' and $79.1 \%$ as 'absent' for Ailanthus. The 'present' locations can be interpreted as locations with a higher probability of being suitable for or at risk of invasion from Ailanthus, not that it is currently present.

This model had an overall accuracy on predicting plots as present or absent of $76.4 \%$, when using the training data for accuracy assessment as well: it correctly predicted presence on 75 of 94 'present' plots, and absence on 129 of 173 'absent' plots (Table 2). When evaluated using the females located via the aerial sketch mapping (Rebbeck et al. 2015), and not used in model development, it accurately predicted 46 of the 59 actual locations for $78 \%$ (Table 2).

\section{Maximum entropy modeling}

A maximum entropy (Maxent) model was calculated from the known locations of female Ailanthus trees and grid points where Ailanthus was present. In contrast to CART, it does not use known absences in its formulation. Notably, years since last harvest was not used as a potential predictor variable so as to create a model not depending on that variable. Since years since last harvest is usually not available, or at least hugely time-consuming to acquire and digitize data back for $50+$ years, we set out to derive

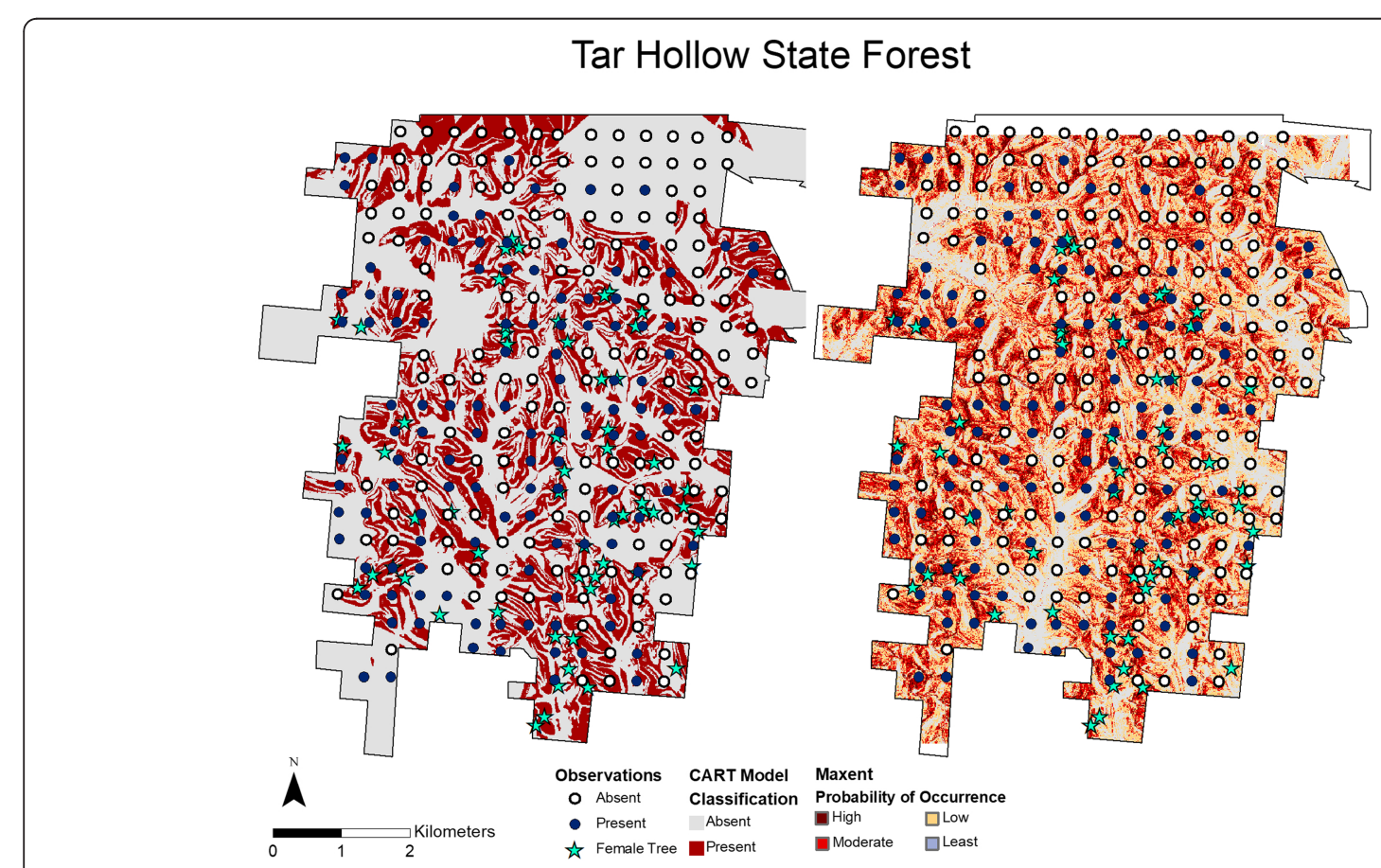

Fig. 3 CART and Maxent modeled presence, or probability of occurrence, of Ailanthus 
Table 2 Accuracy assessment for 267 plots and 59 female Ailanthus trees for the Maxent and CART models

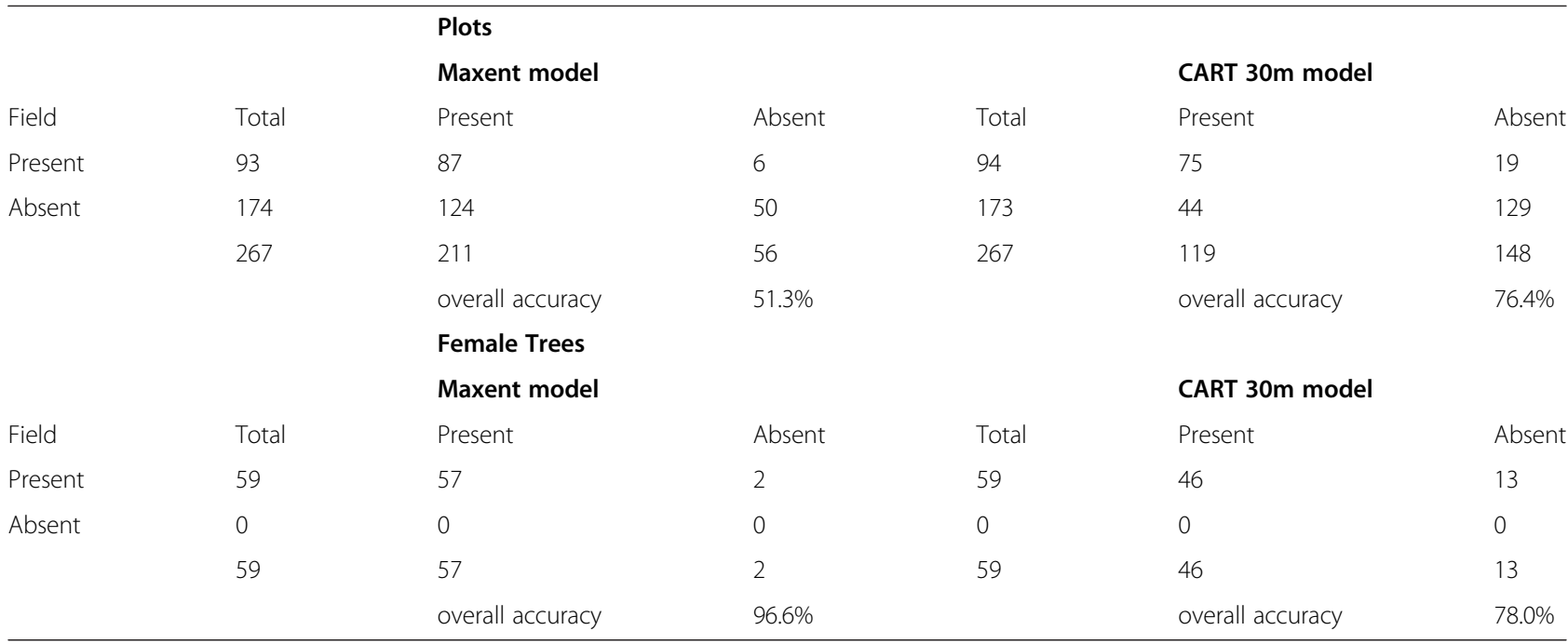

models without that variable. However, the LiDAR-based upper canopy height, which was included, can be considered somewhat a surrogate for the years since last harvest, as tree height would increase with years following harvest. A suite of 38 predictor variables were used to build and test (via set aside records) a Maxent model, with 10 iterations resulting in an AUC of 0.879 and which identified elevation, TPI300, aspect, canopy height, and solar radiation as the top five predictors, respectively, for the presence of Ailanthus (Table 1). Similar to the CART model, this Maxent model therefore uses recent harvest along with variables describing moderate levels of solar radiation and moisture to select the most suitable sites. Classifying the probability of occurrence into least, low, moderate, and high (0-20\%, 21\%-35\%, 36\%-50\%, and 51\%-100\%) placed 1650 ha ( $4077 \mathrm{ac})(35 \%)$ of the study area in moderate to high probability of occurrence. Among the known locations of Ailanthus (female trees and plots with Ailanthus present), $5.3 \%, 21.7 \%, 42.8 \%$, and $30.3 \%$ were predicted among the four categories respectively (Fig. 3, Additional File 4).

For purposes of validation, we combined moderate and high probability $(36 \%-100 \%$ probability) to predict 'present'. The moderate and high classes contained 97\% of the female trees (57 of 59) and $94 \%$ of the $40-\mathrm{m}$ plots (87 of 93) where Ailanthus was present (Table 2).

Similar to the CART model, the probability values produced by Maxent can also be used to identify areas where Ailanthus is least likely to occur. The area associated with the four classes accounted for $26 \%, 39 \%, 27 \%$, and $8 \%$ (least to high, respectively) of THSF (Additional File 4); these probabilities can help in planning field surveys and treatments to manage Ailanthus across the THSF and surrounding landscape. However, as previously mentioned, areas with a higher probability of occurrence may not currently have Ailanthus present. For example, we found that $44 \%$ of the absence plots were modeled to have a moderate to high probability of occurrence; they could be suitable for Ailanthus invasion but no establishment has occurred on those locations. This high proportion of modeled presence (e.g., moderate or high probability of occurrence) on plots with no Ailanthus results in the relatively low overall accuracy of 51\% (Table 2). Knowing the likelihood of these false positives, local knowledge should be used to help interpret the Maxent output and make decisions related to management.

\section{Model evaluation/Comparison}

The two models, representing a CART estimation of $\mathrm{Ai}$ lanthus presence vs absence, and a Maxent estimation of four classes of probability of occurrence show many similarities and some differences (Fig. 3). When comparing presence on CART vs. the high and moderate classes of Maxent, they match well, but with Maxent predicting a greater proportion of suitable habitat (21\% of the landscape with CART vs. $35 \%$ with Maxent). As such, the Maxent model correctly predicts a greater share of the gridded plots with Ailanthus presence (93.5\%) as compared to the CART model (79.8\%) (Table 2). However, absences are consequentially better predicted by the CART model (74.6\% correctly predicted) as compared to the 'least' class of Maxent model (28.7\%). Combining the 'low' and 'least' probability classes correctly predict $56 \%$ of the absences (Additional File 4).

It is important to note that the Maxent model does not use years since last harvest variable, which was the most important factor in the CART model. This was to assess whether a useful model can be built and applied in areas without long-term harvest records. However, it 
does use an estimate of canopy height as deduced from LiDAR analysis. This variable can capture recent harvests and is likely a surrogate for the years since harvest variable. Though this measure of canopy height is not available outside THSF at this time, it does provide the potential for such modeling in future.

\section{Discussion}

This study is part of an overall effort to better understand Ailanthus demography, its habitat preferences across the landscape, and here, its relationship to its position in the landscape. Because the Tar Hollow State Forest has been under state management for many decades, records on harvest and prescribed fire were available and either already digital or digitized by us, going back to the 1930s. Prior to 1930s, THSF had a long history of subsistence farming and timber harvests; these disturbances likely facilitated the establishment of Ailanthus and thus the source for the present-day populations within the THSF. Because seed can persist on the trees throughout the fall and into winter, we hypothesized that wind dispersal and even seed clusters sliding downslope on snow in winter could aid in dispersal of the seed, as reported by Kowarik and Saumel (2007). However, these variables were not significantly important in our models. These data seem to indicate, for this study area, that establishment onto relatively suitable sites is of greater importance than spreading from adjacent upslope or upwind sites. Nonetheless, seed sources need to be available and adjacency and spread must also factor in. Landenberger et al. (2007) did find $A i$ lanthus to be an effective disperser which can spread rapidly in fragmented landscapes where edges and other high light environments occur. Wickert et al. (2017) found a significant relationship between seed production and tree diameter and estimated cumulative seed production in individual Ailanthus can reach ca. 10 million seeds over a 40-year period.

At the time of sampling, $36 \%$ of the systematic plots had Ailanthus present, and $87 \%$ of those had been harvested within the last 40 years. Ailanthus seed germination and seedling establishment have been shown to be greater in recently harvested forests (clearcut and partial cut) than in undisturbed forests (Kota et al. 2007). Timber harvest operations disturb the forest floor and create high light conditions that stimulate the germination of seed-banking species like Ailanthus (e.g., Pickett and McDonnell 1989). All our statistics emphasized the close relationship between years since harvest and Ailanthus presence. Because the more recent harvests are shown to be more likely to have Ailanthus present, the weight of evidence for this site, and likely in many places elsewhere, is that the problem of Ailanthus invasion is growing: ample available seeds and clonal propagation continues and harvest disturbance provides a network for rapid spread of the species. Similar to other studies on invasive plants, disturbance facilitated invasion by Ailanthus, provided a seed source was present (Runkle 1985). Once established, the propagule pressure can drive the subsequent spread of the species (Rouget and Richardson 2003).

Aerial and ground surveys in various locations in southern Ohio also point to an ever-increasing prominence of Ailanthus (Rebbeck et al. 2015), also documented by dendrochronological studies and floristic surveys in Pennsylvania (Kasson et al. 2013), which correspond with global trends for the species (Kowarik and Saumel 2007). Because of society's need for wood products as well as the silvicultural requirements for sustaining oak and creating early successional wildlife habitat, timber harvesting will continue to occur. Thus, the expansion of Ailanthus is likely unless care and treatment are included in the management. Given the changing climatological conditions in the past decades and predicted into the future (Matthews et al. 2018), invasives in general, and perhaps Ailanthus in particular, may benefit at the expense of native species (Alba et al. 2017; Dukes et al. 2009). Similarly, disturbances from insect and disease pests, like the emerald ash borer (Gandhi and Herms 2010), gypsy moth, and hemlock woolly adelgid (Kasson et al. 2013), may provide openings and microsites for increasing Ailanthus.

This study augments the findings of Rebbeck et al. (2017), who found from plot data that prescribed fire does not appear to be a major factor in the presence/absence of Ailanthus, but that harvest history is the dominant driver. We do admit, however, that fire cannot be entirely dismissed as a factor by this study because it cannot be wholly separated from the impacts of harvest - interactions with harvest are likely. It did show up as the eighth most important factor in the RF analysis. However, by incorporating wall-to-wall analysis of multiple variables, we confirm those results but also uncover several other attributes related to the presence of Ailanthus. The overwhelming influence of harvest and the underwhelming influence of fire were apparent in both approaches. Only one of the top 25 variables identified through Random Forest in this study were fire related. Very little is known about the effects of fire on Ailanthus. Lewis (2007) found that saplings are easily topkilled by fire immediately followed by prolific resprouting. However, the longevity of those Ailanthus stems beyond one year was not assessed. In a separate study at THSF, we assessed the direct impacts of prescribed burning on Ailanthus populations; by four years post-burning, Ailanthus germinants and sprouts were poor competitors with faster-growing woody regeneration, primarily Rubus spp. (Rebbeck et al. 2019). Kuppinger et al. (2010) reported that the non-native invasive princess tree (Paulownia tomentosa) increased dramatically immediately following wildfires in Southern Appalachian 
forests, but six years later only persisted on xeric and exposed topographic positions that had high intensity burning.

Our analyses adds to the work of Rebbeck et al. (2017) by pointing to the influence of terrain variables on $\mathrm{Ai}$ lanthus presence. These have not been assessed in a wallto-wall modeling context in any study previously, and were found to be important so that managers can reduce the area under consideration when attacking this invasive tree. The integrated moisture index, the relative sun intensity at $4 \mathrm{pm}$, and the topographic position index at $600 \mathrm{~m}$ all indicate Ailanthus is more likely to occur on hillslopes with medium moisture and solar intensity regimes. Canopy shading is also important. Newly germinated Ailanthus seedlings have been shown to decline in highly shaded environments (Kowarik 1995), although they may survive in low light for up to 7 years (Knüsel et al. 2017) and clonal saplings can survive in shaded forest conditions for $>20$ years until a disturbance gap is created (Knapp and Canham 2000). Similarly, in high light environments, Ailanthus was unable to compete well against the native yellow-poplar (Liriodendron tulipifera) which depends on rapid growth to canopy height during a single period of release (Kota et al. 2007). Our results indicating a preference for moderate moisture levels also is corroborated by other studies. Huebner and Tobin (2006) found greater invasion of exotics on the more mesic, northeast-facing slopes in West Virginia, USA, as did Knüsel et al. (2017) in abandoned chestnut orchards and coppice forests in southern Switzerland. Huebner et al. (2018) found little difference in first-year survival of Ailanthus seedling transplants based on aspect (northeast- vs. southwest-facing), or management regime (single or repeated-burn sites were not different from control, shelterwood or diameter limit cut). In our models, the driest sites also were less likely to have Ailanthus present, likely because forest floor conditions and soil moisture are not as good for Ailanthus germination and establishment in those settings; perhaps also several native oaks and hickories are more competitive in those situations (Iverson et al. 2017; Iverson et al. 2018).

The modeling via CART and Maxent show promising results towards identifying sites more (or less) suitable for Ailanthus invasion. Inspection of maps and verification data show reasonable prediction capabilities by either model so that field personnel could reduce their inspection time should they wish to remove Ailanthus before it becomes a major problem. Each of the models, however, currently have data limitations related to extrapolating the results outside the THSF. Applying the CART or Maxent models to other landscapes requires adequate GIS data for environmental predictions to be made. In the case of the CART, some prior mapping of harvested areas is necessary, while for Maxent, a LiDAR-estimated canopy height variable is necessary. LiDAR is available, readily obtainable, or soon available for large area assessments, so that it can be used as a surrogate for mapping harvest data. Harvest records are either nonexistent or widely dispersed when considering large areas of a mix of public and private lands. Another recent possibility, not explored here, is to use the Landsat archive, dating back as far as the late 1970s or early 1980s, with the Google Earth Engine and its capacity for harmonic regression classification, to identify harvest locations and times over large areas (Adams et al. 2019). Provided suitable data are available, the models could then be used to predict values into the new landscapes based on the training data set used for THSF. Regardless, the models show, via statistics and maps, the types of places and terrains most likely harboring Ailanthus, and can be a starting place for inquires and assessments elsewhere. In general, those places will have had some recent ( $<40$ yrs) harvest, and will more likely occur on mesic, mid-slopes that are 'not too dry, not too wet, not too sunny, and not too shady'. When combined with aerial forays for identification of seed producing females (Rebbeck et al. 2015), identifying Ailanthus locations on the ground with tools those presented here can lead to more effective combat (e.g., inoculating with the biological control Ailanthus wilt, Rebbeck et al. 2013; Kasson et al. 2014) against this aggressive invasive tree.

\section{Conclusions}

Ailanthus altissima is spreading throughout much of the Eastern United States. When forests are disturbed, it can invade and expand quickly if seed sources are nearby. This study evaluated the relationship of Ailanthus presence to harvesting activity, prescribed fire, and other landscape characteristics related to management activities, soil characteristics, topography, and vegetation structure. Field assessments of the demography of Ailanthus and other stand attributes (e.g., fire, harvesting, stand structure) were conducted on 267 sample plots on a 400-m grid throughout the Forest, supplemented by identification of Ailanthus seed-sources via digital aerial sketch mapping during the dormant season. Statistical modeling tools Random Forest, Classification and Regression Trees, and Maxent were used to assess relationships among attributes, then model habitat suitability for Ailanthus presence. A most important predictor of $\mathrm{Ai}$ lanthus presence was some measure of recent timber harvest, either mapped harvest history (CART) or LiDAR-derived canopy height (Maxent). Importantly, the addition of landscape variables added significant information in predicting the presence/absence of Ailanthus. These landscape analyses provide tools and methodologies for assessing landscapes for Ailanthus invasion, as well as those areas with higher potentials for invasion should seed sources become available. 


\section{Additional files}

Additional file 1: Variable list for analysis, including mean values and 1 st and 3rd quartiles. List of variables used in the analysis, along with statistical quartiles. (DOCX $18 \mathrm{~kb}$ )

Additional file 2: Rank order, by Mean Decrease in Gini, of variables in RF model. A listing of variables used in the Random Forest model, presented in decreasing order of importance in the model. (DOCX $17 \mathrm{~kb}$ )

Additional file 3: CART tree diagram showing influence of variables on presence $(=1)$ or absence $(=0)$ of Ailanthus. Tree diagram according to Classification and Regression Trees (CART) output, which shows influence of variables for presence of absence of Ailanthus. (DOCX 15 kb) (EPS $1374 \mathrm{~kb}$ )

Additional file 4: Maxent model statistics showing variable importance, and an evaluation with inventories. These tables show the ranked importance of variables within the Maxent model, along with the evaluation of model outputs against inventory data for presence and absence of Ailanthus within the grid points. (DOCX 15 kb)

\section{Acknowledgments}

We are indebted for the technical support of William Borovicka, Levi Miller, Joan Jolliff, Richard Craig, and David Runkle for leading the field work during the study. We thank the cadre of students from Hocking Technical College, Ohio University, and Ohio State University who contributed to field data collection. We appreciate the support and cooperation from Robert Boyles, Gregory Guess, and staff of the Ohio Department of Natural Resources, Division of Forestry. We appreciate the contributions of Lauren Pile and journal reviewers for reviewing earlier versions of this manuscript. Funding was provided by the Joint Fire Science Program and the USDA Forest Service Northern Research Station.

\section{Authors' contributions}

LRI wrote the initial draft of the paper and performed much of the landscape analysis. MPP conducted a large component of the GIS analysis. JR was the principle person regarding field components. TH and TF performed a large part of the field work. All authors read and approved the final manuscript.

\section{Funding}

Funding was provided by the Joint Fire Science Program (US) (for field assistance) and primarily the Northern Research Station of the USDA Forest Service (for author salaries).

\section{Availability of data and materials}

The datasets used and/or analyzed during the current study are available from the corresponding author on reasonable request.

\section{Ethics approval and consent to participate}

Not applicable.

\section{Consent for publication}

Not applicable.

\section{Competing interests}

The authors declare that they have no competing interests.

Received: 14 February 2019 Accepted: 19 August 2019

Published online: 02 October 2019

\section{References}

Adams B, Matthews S, Prasad AM, Peters M, Iverson L (2019) Mapping floristic gradients of forest composition using an ordination-regression approach with Landsat OLI and terrain data in the Central Hardwoods Region. Forest Ecol Manag 434:87-98

Alba C, NeSmith JE, Fahey C, Angelini C, Flory SL (2017) Methods to test the interactive effects of drought and plant invasion on ecosystem structure and function using complementary common garden and field experiments. Ecol Evol 7:1442-1452

Beers TW, Dress PE, Wensel LC (1966) Aspect transformation in site productivity research. J For 64:691-692
Bory G, Clair-Maczulajtys D (1980) Production, dissemination and polymorphism of seeds in Ailanthus altissima. Rev Gen Bot 88:297-311

Breiman L (2001) Random forest. Mach Learn 45:5-32

Brose PH, Dey DC, Waldrop TA (2014) The fire-oak literature of eastern North America: synthesis and guidelines. Gen Tech Rep NRS-135. U.S. Department of Agriculture, Forest Service, Northern Research Station, Newtown Square, p 98

Call LJ, Nilsen ET (2003) Analysis of spatial patterns and spatial association between the invasive tree-of-heaven (Ailanthus altissima) and the native black locust (Robinia pseudoacacia). Am Midl Nat 150:1-14

Call LJ, Nilsen ET (2005) Analysis of interactions between the invasive tree-ofheaven (Ailanthus altissima) and the native black locust (Robinia pseudoacacia). Plant Ecol 176:275-285

Core Team R (2012) R: a language and environment for statistical computing. R Foundation for Statistical Computing, Vienna https://www.R-project.org. Accessed 15 June 2019

Dibble AC, Zouhar K, Smith JK (2008) Fire and nonnative invasive plants in the northeast bioregion. In: Zouhar K, Smith JK, Sutherland S, Brooks M (eds) Wildland fire in ecosystems: fire and nonnative invasive plants. Gen Tech Rep RMRS-GTR-42-vol. 6. U.S. Department of Agriculture, Forest Service, Rocky Mountain Research Station, Ogden, pp 61-89

Drury SA, Runkle JR (2006) Forest vegetation change in southeast Ohio: do older forests serve as useful models for predicting the successional trajectory of future forests? Forest Ecol Manag 223:200-210

Dukes JS, Pontius J, Orwig D, Garnas J, Rodgers V, Brazee N, Cooke B, Theoharides K, Stange E, Harrington R, Ehrenfeld J, Gurevitch J, Lerdau M, Stinson K, Wick R, Ayres M (2009) Responses of insect pests, pathogens, and invasive plant species to climate change in the forests of northeastern North America: what can we predict? Can J For Res 39:231-248

Dyer JM, Hutchinson T (2019) Topography and soils-based mapping reveals finescale compositional shifts over two centuries within a central Appalachian landscape. For Ecol Manag 433:33-42

Elith J, Phillips SJ, Hastie T, Dudík M, Chee YE, Yates CJ (2011) A statistical explanation of MaxEnt for ecologists. Divers Distrib 17:43-57

ESRI (2009) Arc Hydro Tools -Tutorial Version 1.3. ESRI, Redlands, CA

Evans CW, Moorhead DJ, Bargeron CT, Douce GK (2006) Invasive plant responses to silvicultural practices in the South. The University of Georgia Bugwood Network Tifton, p 52 http://www.invasive.org/silvicsforinvasives.pdf. Accessed 15 June 2019

Fawcett T (2006) An introduction to ROC analysis. Pattern Recogn Lett 27:861-874

Fielding AH, Bell JF (1997) A review of methods for the assessment of prediction errors in conservation presence/absence models. Environ Conserv 24:38-49

Gandhi KK, Herms D (2010) Direct and indirect effects of alien insect herbivores on ecological processes and interactions in forests of eastern North America. Biol Invasions 12:389-405

Heisey RM (1996) Identification of an allelopathic compound from Ailanthus altissima (Simaroubaceae) and characterization of its herbicidal activity. Am J Bot 83:192-200

Hu S (1979) Ailanthus. Arnoldia 39:29-50

Huebner CD, Regula AE, McGill DW (2018) Germination, survival, and early growth of three invasive plants in response to five forest management regimes common to US northeastern deciduous forests. Forest Ecol Manag 425:100-118

Huebner CD, Tobin PC (2006) Invasibility of mature and 15-year-old deciduous forests by exotic plants. Plant Ecol 186:57-68

Hutchinson TF, Boerner RE, Sutherland S, Sutherland EK, Ortt M, Iverson LR (2005) Prescribed fire effects on the herbaceous layer of mixed-oak forests. Can J For Res 35:877-890

Hutchinson TF, Rebbeck J, Long RP (2004) Abundant establishment of Ailanthus altissima (tree-of-heaven) after restoration treatments in an upland oak forest. In: Yaussy DA, Hix DM, Long RP, Goebel PC (eds) Proceedings, 14th Central Hardwood Forest Conference. Gen. Tech. Rep. NE-316. U.S. Department of Agriculture, Forest Service, Northeastern Research Station, Newtown Square, p 514

Hutchinson TF, Yaussy DA, Long RP, Rebbeck J, Sutherland EK (2012) Long-term (13-year) effects of repeated prescribed fires on stand structure and tree regeneration in mixed-oak forests. Forest Ecol Manag 286:87-100

Illick JS, Brouse EF (1926) The Ailanthus tree in Pennsylvania. Pennsylvania Department of Forestry and Water Bulletin 38, Harrisburg, PA. p. 29

Iverson LR, Dale ME, Scott CT, Prasad A (1997) A GIS-derived integrated moisture index to predict forest composition and productivity in Ohio forests. Landsc Ecol 12:331-348

Iverson LR, Hutchinson TF, Peters MP, Yaussy DA (2017) Long-term response of oak-hickory regeneration to partial harvest and repeated fires: influence of light and moisture. Ecosphere 8:e01642 
Iverson LR, Peters M, Bartig J, Rebbeck J, Hutchinson TF, Matthews SN, Stout S (2018) Spatial modeling and inventories for prioritizing investment into oakhickory restoration. Forest Ecol Manag 42:355-366

Jenness J, Brost B, Beier P (2011) Land facet corridor designer. http://www. corridordesign.org. Accessed 15 June 2019

Johnson P, Shifley S, Rogers R (2009) The ecology and silviculture of oaks. CABI Publishing, New York

Kasson MT, Davis MD, Davis DD (2013) The invasive Ailanthus altissima in Pennsylvania: a case study elucidating species introduction, migration, invasion, and growth patterns in the northeastern US. Northeast Nat 20:1-60

Kasson MT, O'Neal ES, Davis DD (2014) Expanded host range testing for Verticillium nonalfalfae: potential biocontrol agent against the invasive Ailanthus altissima. Plant Dis 99:823-835

Knapp LB, Canham CD (2000) Invasion of an old-growth forest in New York by Ailanthus altissima: sapling growth and recruitment in canopy gaps. J Torrey Bot Soc 127:307-315

Knüsel S, De Boni A, Conedera M, Schleppi P, Thormann JJ, Frehner M, Wunder J (2017) Shade tolerance of Ailanthus altissima revisited: novel insights from southern Switzerland. Biol Invasions 19:455-461

Kota NL, Landenberger RE, McGraw JB (2007) Germination and early growth of Ailanthus and tulip poplar in three levels of forest disturbance. Biol Invasions 9:197-211

Kowarik I (1995) Clonal growth in Ailanthus altissima on a natural site in West Virginia. J Veg Sci 6:853-856

Kowarik I, Saumel I (2007) Biological flora of Central Europe: Ailanthus altissima (Mill.) Swingle. Perspect Plant Ecol 8:207-237

Kuppinger DM, Jenkins MA, White PS (2010) Predicting the post-fire establishment and persistence of an invasive tree species across a complex landscape. Biol Invasions 12:3473-3484.

Landenberger RE, Kota NL, McGraw JB (2007) Seed dispersal of the non-native tree Ailanthus altissima into contrasting environments. Plant Ecol 192:55-70

Lewis KC (2007) Control techniques and management implications for the invasive Ailanthus altissima (tree of heaven). MS Thesis, Ohio University, Athens. https://etd.ohiolink.edu/. Accessed 15 June 2019

Matthews SN, Iverson L, Peters M, Prasad AM (2018) Assessing potential climate change pressures throughout this century across the Conterminous United States: mapping plant hardiness zones, heat zones, growing degree days, and cumulative drought severity throughout this century. Research Map NRS-9, U.S. Department of Agriculture, Forest Service. Northern Research Station, Newtown Square, p 31

Menze BH, Kelm BM, Masuch R, Himmelreich U, Bachert P, Petrich W, Hamprecht FA (2009) A comparison of random forest and its Gini importance with standard chemometric methods for the feature selection and classification of spectral data. BMC Bioinformatics 10:213

Ohio Division of Forestry (2010) Ohio forest resource assessment. Ohio Department of Natural Resources. Division of Forestry, Columbus

Ohio Division of Wildlife (2015) Ohio's state wildlife action plan. Ohio Department of Natural Resources, Columbus

OSIP_I (2017) Ohio statewide imagery program, Ohio geographically referenced information program. http://gis5.oit.ohio.gov/geodatadownload/. Accessed 16 May 2017

Peters M, Iverson LR, Prasad AM (2010) Using an integrated moisture index to assess forest composition and productivity. Chapter 11. In: Eredics P (ed) Mapping Forestry. ESRI Press, Redlands, pp 41-44

Phillips SJ, Dudík M (2008) Modeling of species distributions with Maxent: new extensions and a comprehensive evaluation. Ecography 31:161-175

Pickett STA, McDonnell MJ (1989) Changing perspectives in community dynamics: A theory of successional forces. Trends Ecol Evol 4:241-245.

Prasad AM, Iverson LR, Liaw A (2006) Newer classification and regression tree techniques: bagging and random forests for ecological prediction. Ecosystems 9:181-199

Rebbeck J, Hutchinson T, Iverson L, Yaussy D, Fox T (2017) Distribution and demographics of Ailanthus altissima in an oak forest landscape managed with timber harvesting and prescribed fire. Forest Ecol Manag 401:233-241

Rebbeck J, Hutchinson T, Iverson L (2019) Effects of prescribed fire and steminjection herbicide on Ailanthus altissima demographics and survival. Forest Ecol Manag 439:122-131.

Rebbeck J, Kloss A, Bowden M, Coon C, Hutchinson TF, Iverson L, Guess G (2015) Aerial detection of seed-bearing female Ailanthus altissima: a cost-effective method to map an invasive tree in forested landscapes. For Sci 6:1068-1078
Rebbeck J, Malone MA, Short DPG, Kasson MT, O’Neal ES, Davis DD (2013) First report of Verticillium wilt caused by Verticillium nonalfalfae on tree-ofheaven (Ailanthus altissima) in Ohio. Plant Dis 97:999

Rouget M, Richardson DM (2003) Inferring process from pattern in plant invasions: a semimechanistic model incorporating propagule pressure and environmental factors. Am Nat 162:713-724

Runkle JR (1985) Disturbance regimes in temperate forests. In: Pickett S, White P (eds) The ecology of natural disturbance and patch dynamics. Academic Press, New York, pp 17-33

Tarboton D (1997) A new method for the determination of flow directions and contributing areas in grid digital elevation models. Water Resour Res 33:309-319

Wickert KL, O'Neal ES, Davis DD, Kasson MT (2017) Seed production, viability, and reproductive limits of the invasive Ailanthus altissima (tree-of-heaven) within invaded environments. Forests 8:226

Yaussy DA, Nowacki GJ, Schuler TM, Dey DC (2008) Developing a unified monitoring and reporting system: a key to successful restoration of mixedoak forests throughout the central hardwood region. In: Deal RL (ed) Proceedings, 2007 National Silviculture Workshop. Gen. Tech. Rep. GTR-PNW733. U.S. Department of Agriculture, Forest Service, Pacific Northwest Research Station, Portland, pp 281-288

Zouhar K, Smith JK, Sutherland S, Brooks ML (2008) Wildland fire in ecosystems: fire and nonnative invasive plants. Gen. Tech. Rep. RMRS-GTR-42-vol. 6. U.S. Department of Agriculture, Forest Service, Rocky Mountain Research Station, Ogden, p 355

\section{Submit your manuscript to a SpringerOpen ${ }^{\circ}$ journal and benefit from:}

- Convenient online submission

- Rigorous peer review

- Open access: articles freely available online

- High visibility within the field

- Retaining the copyright to your article

Submit your next manuscript at $>$ springeropen.com 